\title{
Frekuensi Hepatitis B dan Hepatitis C Positif pada Darah Donor di Unit Transfusi Darah Cabang Padang pada Tahun 2012
}

\author{
Dewi Oktavia ${ }^{1}$, Rismawati Yaswir $^{2}$, Nora Harminarti ${ }^{3}$
}

\begin{abstract}
Abstrak
Infeksi virus hepatitis B dan hepatitis C akut bisa bergejala (simptomatik) atau tidak bergejala (asimptomatik). Penderita asimptomatik terdeteksi pada pemeriksaan skrining donor darah. Tujuan penelitian ini adalah untuk mengetahui frekuensi hepatitis B dan hepatitis C positif pada darah donor. Telah dilakukan penelitian deskriptif retrospektif terhadap frekuensi hepatitis B dan hepatitis C positif pada darah donor di Unit Transfusi Darah Cabang Padang tahun 2012. Jumlah donor yang tercatat di Unit Transfusi Darah Cabang Padang mulai dari Januari 2012 sampai Desember 2012 adalah 26.306 donor, terdiri dari 19.949 donor sukarela dan 6.357 donor pengganti. Jumlah total hepatitis B positif yang ditemukan adalah sebanyak 974 donor sedangkan Jumlah total hepatitis $\mathrm{C}$ positif yang ditemukan adalah sebanyak 157 donor. Dari seluruh donor yang diperiksa didapatkan secara keseluruhan persentase hepatitis B positif atau reaktif sebesar $(3,7 \%)$ dan persentase hepatitis $C$ positif atau reaktif $(0,6 \%)$. Berdasarkan jenis donor didapatkan hepatitis B positif pada donor sukarela adalah $634(3,2 \%)$ sedangkan donor pengganti $340(5,3 \%)$. Untuk hepatitis C, berdasarkan jenis donor didapatkan hepatitis C positif pada donor sukarela adalah $98(0,5 \%)$ sedangkan donor pengganti 59 (0,9\%). Secara keseluruhan didapatkan persentase hepatitis $B$ dan hepatitis $C$ positif ditemukan lebih tinggi pada donor pengganti daripada donor sukarela.
\end{abstract}

Kata kunci: hepatitis $B$, hepatitis $C$, donor sukarela, donor pengganti

\section{Abstract}

The infection of hepatitis $B$ and hepatitis $C$ acute can be symptomatic or asymptomatic. Asymptomatic are detected in blood donors screening test. The objective of this study was to find out the frequency of positive hepatitis $B$ and hepatitis $C$ in blood donors at Blood Transfusion Unit Padang Branch on 2012. This study was conducted using descriptive retrospective research design. Number of donors which recorded at Blood Transfusion Unit Padang Branch start from January 2012 to December 2012 were 26.306 donors, consist of 19.949 voluntary donors and 6.357 family donors. Results showed the total number of hepatitis $B$ positive were found 974 donors and the total number of hepatitis $C$ positive 157 donors. Entirely, from all of donors that has been tested the percentage of hepatitis $B$ positive or reactive were $3.7 \%$ and the percentage of hepatitis $C$ positive or reactive were $0.6 \%$. Based on a donors form, hepatitis B positive were found 634 (3.2\%) from voluntary donors whereas 340 (5.3\%) were found from family donors. For hepatitis $C$, based on a donors form, hepatitis $C$ positive were found $98(0.5 \%)$ in voluntary donors whereas 59 $(0.9 \%)$ in family donors. Overall the percentage of hepatitis $B$ and $C$ positive were found higher in family donors than voluntary donors.

Keywords: hepatitis $B$, hepatitis $C$, voluntary donors, family donors

Affiliasi penulis: 1. Prodi Profesi Dokter FK Unand (Faklutas Kedokteran Universitas Andalas Padang), 2. Bagian Patologi Klinik FK Unand, 3. Bagian Parasitologi FK Unand

Korespondensi: Dewi Oktavia, Email: dhewy_cenyow@yahoo.com Telp: 085274350208

\section{PENDAHULUAN}

Salah satu penyebab hepatitis adalah virus. Virus yang spesifik untuk peradangan hati adalah virus hepatitis $A, B, C, E, F$ dan G. Dari semua virus tersebut, 
infeksi virus hepatitis B dan hepatitis C merupakan masalah kesehatan. ${ }^{1}$

Hepatitis B adalah penyakit yang disebabkan oleh virus hepatitis $B$ yang telah diidentifikasi dengan mikroskop elektron sebagai partikel berukuran $42 \mathrm{~nm}$ (partikel Dane). Infeksi virus ini pada manusia bisa mempunyai gejala (simptomatik), namun juga bisa tidak bergejala (asimptomatik). Penderita yang terinfeksi virus hepatitis B asimptomatik terdeteksi pada saat pemeriksaan darah donor sukarela maupun donor darah pengganti di unit-unit transfusi darah. Prevalensi penderita yang tidak mempunyai gejala (diketahui dengan ditemukannya Hepatitis $B$ surface Antigen [HBsAg]) bervariasi antar populasi, prevalensi dari serendah $0,1 \%$ diantara donor darah sukarela di Inggris dan Amerika Serikat tapi bisa setinggi 15\% di negara lain. ${ }^{2}$

Hepatitis $C$ adalah penyakit yang disebabkan oleh virus hepatitis $C$ yang merupakan virus yang relatif baru ditemukan. Virus ini terbukti sebagai penyebab utama hepatitis non-A, non- $B$ pasca transfusi. Sekitar $60-70 \%$ penderita dengan infeksi virus hepatitis $\mathrm{C}$ akan berkembang menjadi pengidap hepatitis kronis (termasuk sirosis) dan sebagian dari penderita ini akan berkembang menjadi karsinoma sel hati. $^{3}$

Adanya penyaringan terhadap HBsAg dan Anti Hepatitis C Virus (Anti-HCV) pada donor darah atau produk darah serta donor organ merupakan hal yang sangat esensial, untuk mencegah penularan kedua virus ini. Pemeriksaan anti HCV pada donor darah memiliki sensitivitas yang terbatas, kira-kira lebih dari $20 \%$ darah yang terinfeksi masih belum dapat dideteksi. $^{1}$

Transfusi darah adalah pemberian infus seluruh darah atau suatu komponen darah dari suatu individu (donor) ke individu lain (resipien) yang bertujuan untuk mengganti atau menambah komponen darah yang hilang atau jumlah yang tidak mencukupi. ${ }^{4}$

Berdasarkan Pasal 6 Peraturan Menteri Kesehatan No.478 tanggal 5 Oktober 1990, darah yang diberikan pada pasien haruslah aman dari bibit penyakit sehingga tidak tertular kepada pasien. ${ }^{5}$

Transfusi darah memegang peran penting dalam menyelamatkan pasien yang mengalami kekurangan darah. Namun pada saat yang sama transfusi darah juga dapat berperan sebagai media yang potensial untuk menularkan penyakit. Salah satu penyakit yang dapat menular melalui transfusi darah adalah hepatitis B (HBV). ${ }^{5}$

Transfusi darah telah menjadi prosedur yang bersifat rutin sehingga bahaya transfusi ini sendiri kadang tidak diperhatikan. Mortalitas sebenarnya yang disebabkan oleh transfusi sulit untuk diperkirakan dan angkanya pasti bervariasi dari suatu daerah dengan daerah lain. ${ }^{2}$

Pencegahan penyakit yang ditularkan melalui darah, Indonesia umumnya melakukan skrining terhadap HBV, HCV, HIV (Human Immunodeficiency virus) dan VDRL. Bila hasil uji negatif maka darah tersebut dianggap layak untuk ditransfusikan. ${ }^{5}$

Penularan HBV dicegah melalui transfusi darah, Indonesia umumnya memberlakukan standar pemeriksaan $\mathrm{HBsAg}$ untuk skrining terhadap $\mathrm{HBV}^{5}$ Pada tahun 2001, Nova Sri Hartati telah melakukan penelitian di Unit Transfusi Darah Cabang PMI Padang dan didapatkan prevalensi HBsAg adalah sebesar $4,24 \%{ }^{6}$ Penelitian ini dilanjutkan oleh Elvanetty pada tahun 2002 dan didapatkan prevalensi HBsAg positif pada darah donor adalah sebesar 4,19\%. ${ }^{1}$

Data dari Unit Transfusi Darah Palang Merah Indonesia (UTD PMI) cabang Padang pada tahun 2005 memperlihatkan bahwa ada 591 orang (3,15\%) dari 18.773 donor darah sukarela dan donor pengganti dengan HBsAg positif. ${ }^{5}$

Pada tahun 2000 Taufik Ashal melakukan penelitian mengenai prevalensi anti-HCV positif di UTDC PMI Padang dan didapatkan hasil prevalensinya adalah sebesar $0,95 \%$ pada darah donor.7Kemudian Rizka Hidayani melanjutkan penelitian di Unit Transfusi Darah (UTD) Cabang PMI Padang pada tahun 2004 dan didapatkan prevalensi hepatitis $\mathrm{C}$ positif $1,06 \%{ }^{4}$

Berdasarkan penelitian yang sudah dilakukan diatas perlu dilakukan penelitian lanjutan yang menggambarkan frekuensi hepatitis $B$ dan hepatitis $C$ positif pada darah donor di UTD PMI Cabang Padang pada tahun 2012 menurut jenis donor darah sukarela, donor pengganti, dan bagaimana persentase antara keduanya. 


\section{METODE}

Penelitian dilaksanakan di UTD Cabang Padang yang merupakan salahsatu UTD di Sumatera Barat yang paling aktif melaksanakan kegiatan transfusi darah. Studi ini terhitung mulai dari Januari 2012-Desember 2012. Populasi adalah semua donor yang menyumbangkan darahnya di Unit Transfusi Darah Cabang Padang pada tahun 2012. Populasi ini dijadikan sampel dalam penelitian ini. Dari semua donor darah pada UTD Cabang Padang selama tahun 2012 tercatat jumlah donor dan jumlah HbsAg dan Anti-HCV positif berdasarkan Donor Sukarela dan Donor Pengganti. Semua data yang diperoleh diolah secara manual dan dihitung persentasenya kemudian disajikan dalam bentuk tabel distribusi frekuensi untuk diambil kesimpulan.

HASIL

Tabel 1. Distribusi frekuensi hepatitis B positif pada donor sukarela dan donor pengganti

\begin{tabular}{cccc}
\hline \multirow{2}{*}{ Bulan(2012) } & \multicolumn{2}{c}{ Hepatitis B positif } & \\
\cline { 2 - 3 } & Donor & n & \\
& Sukarela & Pengganti & \\
\hline Januari & 53 & 20 & 73 \\
Februari & 61 & 38 & 99 \\
Maret & 40 & 46 & 86 \\
April & 39 & 22 & 61 \\
Mei & 54 & 18 & 72 \\
Juni & 58 & 14 & 72 \\
Juli & 50 & 14 & 64 \\
Agustus & 41 & 24 & 65 \\
September & 60 & 49 & 109 \\
Oktober & 61 & 24 & 85 \\
November & 57 & 22 & 79 \\
Desember & 60 & 49 & 109 \\
\hline
\end{tabular}

Pada Tabel 1 terlihat bahwa frekuensi hepatitis B positif secara keseluruhan adalah 974 donor. Frekuensi hepatitis B positif pada donor sukarela adalah 634 sedangkan donor pengganti adalah 340 .

Berdasarkan jenis donor, frekuensi hepatitis B positif lebih tinggi pada donor sukarela daripada donor pengganti. Frekuensi hepatitis B positif tertinggi terdapat pada bulan September dan bulan Desember dengan jumlah 109 dan terendah pada bulan April dengan jumlah 61 .
Tabel 2. Distribusi frekuensi hepatitis C positif pada donor sukarela dan donor pengganti

\begin{tabular}{cccc}
\hline \multirow{2}{*}{ Bulan(2012) } & \multicolumn{2}{c}{ Hepatitis C positif } & n \\
\cline { 2 - 3 } & $\begin{array}{c}\text { Donor } \\
\text { Sukarela }\end{array}$ & $\begin{array}{c}\text { Donor } \\
\text { Pengganti }\end{array}$ & \\
\hline Januari & 6 & 2 & 8 \\
Februari & 9 & 5 & 14 \\
Maret & 9 & 5 & 14 \\
April & 7 & 3 & 10 \\
Mei & 7 & 6 & 13 \\
Juni & 7 & 4 & 11 \\
Juli & 9 & 4 & 13 \\
Agustus & 4 & 4 & 8 \\
September & 12 & 7 & 19 \\
Oktober & 8 & 6 & 14 \\
November & 11 & 5 & 16 \\
Desember & 9 & 8 & 17 \\
\hline
\end{tabular}

Pada Tabel 2 terlihat bahwa frekuensi hepatitis C positif secara keseluruhan 157 donor. Frekuensi hepatitis C positif pada donor sukarela adalah 98 donor sedangkan donor pengganti adalah 59 donor.

Berdasarkan jenis donor, frekuensi hepatitis C positif lebih tinggi pada donor sukarela daripada donor pengganti. Frekuensi hepatitis C positif tertinggi terdapat pada bulan September dan bulan Desember dengan jumlah 19 dan terendah pada bulan Januari dan Agustus dengan jumlah 8.

Tabel 3. Distribusi frekuensi Jumlah donor, Jumlah HBsAg dan Anti HCV Positif berdasarkan donor sukarela dan donor pengganti

\begin{tabular}{lcccccc}
\hline \multirow{2}{*}{ JENIS } & \multicolumn{2}{c}{ Jumlah donor } & HBsAg & & Anti & HCV \\
DONOR & & & Positif & & Positif & \\
\cline { 2 - 7 } & $\mathbf{f}$ & $\%$ & $\mathbf{f}$ & $\%$ & $\mathbf{f}$ & $\%$ \\
\hline DS & 19.949 & 75,8 & 634 & 3,2 & 98 & 0,5 \\
DP & 6.357 & 24,2 & 340 & 5,3 & 59 & 0,9 \\
\hline JUMLAH & 26.306 & 100 & 974 & 3,7 & 157 & 0,6 \\
\hline
\end{tabular}

Pada Tabel 3 terlihat bahwa jumlah donor sukarela yaitu 19.949 donor atau $75,8 \%$ dari semua donor, yang berarti lebih banyak daripada donor pengganti yaitu 6.357 donor atau $24,2 \%$ dari semua donor, tetapi persentase HBsAg positif pada donor pengganti $(5,3 \%)$ lebih besar daripada donor sukarela 
$(3,2 \%)$. Begitu juga dengan persentase Anti HCV positif donor pengganti $(0,9 \%)$ juga lebih besar daripada donor sukarela $(0,5 \%)$.

\section{PEMBAHASAN}

Berdasarkan data yang diperoleh dari Tabel 1 dapat diketahui jumlah donor di UTDC PMI Padang pada tahun 2012 sebanyak 26.306 donor dan jumlah hepatitis B positif atau reaktif secara keseluruhan adalah $974(3,7 \%)$ donor. Dari jumlah tersebut didapatkan persentase hepatitis B positif pada donor sukarela adalah $634(3,2 \%)$ sedangkan donor pengganti adalah 340 (5,3\%). Sebelumnya telah dilakukan pula penelitian oleh Nova Sri Hartati di Unit Transfusi Darah Cabang PMI Padang pada tahun 2001 dimana prevalensi HBsAg didapatkan sebesar $4,24 \%$. ${ }^{6}$ Penelitian yang dilakukan oleh Elvanetty pada tahun 2002 didapatkan prevalensi HBsAg positif pada darah donor sebesar $4,19 \%{ }^{1}$

Adanya penurunan angka HBsAg mungkin disebabkan dampak dari pelaksanaan program imunisasi terhadap hepatitis B yang telah dilakukan oleh pemerintah dan pemeriksaan $\mathrm{HBsAg}$ terhadap serum donor yang menyumbangkan darahnya. Berdasarkan jenis donor, frekuensi hepatitis B positif lebih tinggi pada donor sukarela daripada donor pengganti. Namun persentasenya lebih tinggi pada donor pengganti daripada donor sukarela. Hal ini disebabkan karena pendonor sukarela biasanya melakukan donor darah secara rutin.

Berdasarkan data yang diperoleh dari Tabel 2 dapat diketahui jumlah donor di Unit Transfusi Darah Cabang PMI Padang pada tahun 2012 sebanyak 26.306 donor dan jumlah hepatitis $C$ positif atau reaktif secara keseluruhan adalah $157(0,6 \%)$ donor. Hal ini sesuai dengan yang dilaporkan oleh Suwandhi Widjaja tahun 1996 bahwa prevalensi hepatitis C positif pada donor darah di Indonesia berkisar antara 0,5-3,4\%. ${ }^{3}$ Penelitian oleh Taufik Ashal di UTDC PMI Padang pada tahun 2000, dan didapatkan frekuensi anti-HCV positif $0,95 \%$ pada darah donor. ${ }^{7}$

Rizka Hidayani melanjutkan penelitian di Unit Transfusi Darah Cabang PMI Padang pada tahun 2004, dan didapatkan frekuensi hepatitis C positif $1,06 \%{ }^{4}$ Persentase hepatitis $\mathrm{C}$ positif pada donor sukarela adalah 98 (0,5\%) sedangkan donor pengganti adalah 59 (0,9\%). Berdasarkan jenis donor, frekuensi hepatitis $C$ positif lebih tinggi pada donor sukarela daripada donor pengganti. Namun persentasenya lebih tinggi pada donor pengganti daripada donor sukarela. Hal ini mungkin disebabkan karena pendonor sukarela biasanya melakukan donor darah secara rutin.

Berdasarkan data yang diperoleh dari Tabel 3 dapat diketahui bahwa jumlah donor sukarela meningkat persentasenya sebesar $75,8 \%$ dan donor pengganti menurun menjadi $24,2 \%$ jika dibandingkan dengan penelitian Elvanetty tahun 2002 yang mendapatkan persentase donor sukarela $62,59 \%$ dan donor pengganti $37,41 \%{ }^{1}$ Peningkatan jumlah donor darah sukarela ini mungkin karena telah adanya kesadaran dari masyarakat untuk membantu sesama melalui tindakan donor darah sukarela.

\section{SIMPULAN}

Frekuensi hepatitis B positif pada donor sukarela yaitu $634(3,2 \%)$ donor pengganti yaitu 340 $(5,3 \%)$.Berdasarkan jenis donor, persentase hepatitis $B$ positif lebih tinggi pada donor pengganti daripada donor sukarela. Frekuensi hepatitis C positif pada donor sukarela yaitu $98(0,5 \%)$ donor pengganti yaitu $59(0,9 \%)$. Berdasarkan jenis donor, persentase hepatitis $\mathrm{C}$ positif lebih tinggi pada donor pengganti daripada donor sukarela.

\section{DAFTAR PUSTAKA}

1. Elvanetty. Prevalensi $\mathrm{HBsAg}$ dan anti $\mathrm{HCV}$ positif pada darah donor di unit transfusi darah cabang palang merah Indonesia Padang periode April 2001-Maret 2002 (skripsi). Padang: Universitas Andalas; 2002.

2. Nurtjojo HK. Haematology (terjemahan). Edisi ke-5. Jakarta: EGC;1995.

3. Widjaja S. Virus hepatitis B, C, dan G. Jakarta: Grasindo;1999.

4. Hidayani R. Frekuensi anti HCV positif pada darah donor di unit transfusi darah cabang PMI Padang periode 1 Juli 2002-30 Juni 2004 (skripsi). Padang: Universitas Andalas; 2004.

5. Uji Anti-HBc pada donor darah yang sudah lolos skrining pada unit tranfusi darah PMI 
cabang Padang (artikel Ilmiah). Padang: Universitas Andalas; 2010.

6. Hartati NS. Frekuensi HBsAg positif pada uji saring darah Di PMI cabang Padang Januari
2001 sampai Desember 2001 (skripsi).

Padang: Universitas Andalas; 2002.

7. Ashal T. Frekuensi virus hepatitis $C$ positif pada dara donor di UTDC PMI Padang (skripsi).

Padang: Universitas Andalas,.2000. 